\title{
Production and reproduction of Fleckvieh, Brown Swiss, and 2 strains of Holstein-Friesian cows in a pasture-based, seasonal-calving dairy system
}

\author{
V. Piccand, ${ }^{* 1}$ E. Cutullic, ${ }^{*}$ S. Meier,† F. Schori,ł P. L. Kunz, ${ }^{*}$ J. R. Roche,† and P. Thomet ${ }^{\star}$ \\ *Bern University of Applied Science, School of Agricultural, Forest and Food Sciences, 3052 Zollikofen, Switzerland \\ †DairyNZ Limited, Private Bag 3221, Hamilton 3240, New Zealand \\ $\ddagger$ Agroscope Liebefeld-Posieux Research Station ALP, 1725 Posieux, Switzerland
}

\begin{abstract}
The first objective of this study was to compare the productive and reproductive performance of HolsteinFriesian (CH HF), Fleckvieh (CH FV), and Brown Swiss (CH BS) cows of Swiss origin with New Zealand Holstein-Friesian (NZ HF) cows in pasture-based compact-calving systems; NZ HF cows were chosen as the reference population for such grazing systems. The second objective was to analyze the relationships within and between breeds regarding reproductive performance, milk yield, and body condition score (BCS) dynamics. On 15 commercial Swiss farms, NZ HF cows were paired with Swiss cows over 3 yr. Overall, the study involved 259 complete lactations from 134 cows: 131 from $58 \mathrm{NZ} \mathrm{HF}, 40$ from $24 \mathrm{CH} \mathrm{HF}, 43$ from $27 \mathrm{CH} \mathrm{FV}$, and 45 from $25 \mathrm{CH}$ BS cows. All production parameters were affected by cow breed. Milk and energy-corrected milk yield over $270 \mathrm{~d}$ of lactation differed by $1,000 \mathrm{~kg}$ between the 2 extreme groups; $\mathrm{CH}$ HF having the highest yield and $\mathrm{CH}$ BS the lowest. The NZ HF cows had the greatest milk fat and protein concentrations over the lactation and exhibited the highest lactation persistency. Body weight differed by $90 \mathrm{~kg}$ between extreme groups; NZ HF and CH BS being the lightest and $\mathrm{CH} \mathrm{HF}$ and $\mathrm{CH} \mathrm{FV}$ the heaviest. As a result, the $2 \mathrm{HF}$ strains achieved the highest milk production efficiency (270-d energy-corrected milk/body weight $\left.{ }^{0.75}\right)$. Although less efficient at milk production, $\mathrm{CH} \mathrm{FV}$ had a high 21-d submission rate $(86 \%)$ and a high conception rate within 2 inseminations (89\%), achieving high pregnancy rates within the first 3 and 6 wk of the breeding period (65 and 81\%, respectively). Conversely, poorer reproductive performance was recorded for $\mathrm{CH}$ HF cows, with NZ HF and CH BS being intermediate. Both BCS at nadir and at $100 \mathrm{~d}$ postpartum had a positive effect on the 6 -wk pregnancy rate, even when breed was included in the model. The BCS at $100 \mathrm{~d}$ of lactation also positively
\end{abstract}

Received December 2, 2012.

Accepted May 6, 2013.

${ }^{1}$ Corresponding author: vpi@swissgenetics.ch affected first service conception rate. In conclusion, despite their high milk production efficiency, even in low-input systems, CH HF were not suited to pasturebased seasonal-calving production systems due to poor reproductive performance. On the contrary, $\mathrm{CH}$ FV fulfilled the compact-calving reproduction objectives and deserve further consideration in seasonal calving systems, despite their lower milk production potential. Key words: breed, genetics, efficiency, compact calving pasture system

\section{INTRODUCTION}

Grazing is often considered as the most sustainable way to produce milk, due to lower production costs, higher quality end products, and greater social acceptance (Peyraud et al., 2010; Thomet et al., 2011). In many parts of the world pasture-based systems are synonymous with compact seasonal calving to match feed demand and pasture growth (Holmes et al., 2007).

To achieve a short interval between calving and successful rebreeding, the seasonal-calving, pasture-based system requires a specific cow (Horan et al., 2005b; Macdonald et al., 2008), which can produce milk efficiently with minimal supplementation and has the capacity to reestablish pregnancy within $83 \mathrm{~d}$ of the previous calving. Not all breeds share these characteristics, because genotype $\times$ environment interactions exist for milk production and reproduction (Kolver et al., 2002; Fulkerson et al., 2008; Cutullic et al., 2011). For example, North American (NA) Holstein-Friesian (HF) cows selected in high feed allowance and highstarch feeding systems cannot take full advantage of their milk production potential in low supplementation pasture-based systems, and thus fail to compensate for their poorer reproductive performance when compared with New Zealand (NZ) HF cows selected for such systems with emphasis on production of milk components, fertility, and longevity (Harris and Kolver, 2001). Biologically, this selection divergence has also led to differences in metabolism and nutrient partitioning, reflected by differences in BCS dynamics (Roche et al., 2006; 
McCarthy et al., 2007a), especially when resources are limited (Macdonald et al., 2008).

Over the last $40 \mathrm{yr}$, most international dairy breeds have experienced the introduction of NA genetic material, with the principal aim of rapidly increasing milk production. For example, the Swiss $(\mathbf{C H})$ Brown Swiss (BS) population contains more than $78 \%$ NA BS genes (Hagger, 2005). The original Simmental now represents only $12 \%$ of the Swiss Red and White dairy cattle population and is, instead, largely dominated by the Red Holstein and their crosses (Simmental $\times$ Red Holstein), such as the CH Fleckvieh (FV) population (A. Bigler, Swissherdbook, Zollikofen, Switzerland, personal communication). This large introduction of HF genes was not observed in the Austrian or German Fleckvieh populations; thus, these populations are less dairy-typed than the $\mathrm{CH}$ FV population we studied. Although more emphasis was placed on functional traits than in other countries (Böbner, 1994), and although selected within grass-based low-concentrate systems in Switzerland, the suitability of the 3 main Swiss breeds for the grazing-based compact-calving system is uncertain in terms of both production efficiency and reproductive performance.

The first objective of this study was to compare, in a pasture-based, compact-calving system, the productive and reproductive performance of $\mathrm{CH} \mathrm{HF}, \mathrm{CH} F V$, and $\mathrm{CH}$ BS cows of Swiss origin with NZ HF cows, the latter being chosen as a reference population recognized for their ability to achieve good production and reproduction results in such systems (Horan et al., 2004, 2005b; Macdonald et al., 2008). The second objective was to analyze, within and between breeds, the relationships among reproductive performance, milk yield, and BCS dynamics.

\section{MATERIALS AND METHODS}

\section{Experimental Design}

The present study took place over 3 yr on 15 commercial dairy farms in Switzerland (14, 13, and 10 farms in years 2007, 2008, and 2009, respectively). At the start of the experiment, NZ HF pregnant heifers were imported from Ireland and randomly allocated to the farms involved. We cannot exclude that differences in rearing and the effect of shipment could have influenced the NZ HF cows' performance. However, importation took place $150 \pm 12 \mathrm{~d}$ before first calving, mitigating the potential effects of long-distance transportation.

On each farm, each NZ HF cow was paired with a Swiss cow of the breed present on the farm $(3,7$, and 5 farms with $\mathrm{CH} \mathrm{HF}, \mathrm{CH} F V$, and $\mathrm{CH}$ BS, respectively). Pairs of NZ HF and Swiss cows were reallocated each year according to calving date and age. In the first year, mean birth date of heifers was Jan. 28, $2005 \pm$ $45 \mathrm{~d}$ and first calving date was Feb. 17, $2007 \pm 17 \mathrm{~d}$. In the following years, experimental cows calved, on average, on Feb. $22 \pm 27 \mathrm{~d}$ and on Feb. $21 \pm 33$ days. Within pair, calving dates differed on average by $13 \pm$ $9 \mathrm{~d}$. The trial cows were managed as part of the main herd with the farmer in charge of all management decisions concerning his herd.

The study involved 259 complete lactations from 134 cows: 131 lactations from 58 NZ HF cows, 40 from $24 \mathrm{CH} \mathrm{HF}$ cows, 43 from $27 \mathrm{CH} \mathrm{FV}$ cows, and 45 from $25 \mathrm{CH}$ BS cows. Cows were in first, second, and third lactation in 2007, 2008, and 2009, respectively (96, 98, and 65 lactations, respectively).

Over the $3 \mathrm{yr}$ of the experiment, the genetic index of NZ HF cows (see the Animals section for a description of indices) was similar among the farms with $\mathrm{CH} \mathrm{HF}$, $\mathrm{CH} \mathrm{FV}$, or $\mathrm{CH}$ BS cows $(P=0.68)$. At the farm level, despite the low number of NZ HF cows randomly attributed per farm, only 2 farms and 1 farm (out of 15) had a lower or higher genetic merit than the population average $(P<0.05)$, respectively. Similarly, genetic indices were similar across farms for $\mathrm{CH} \mathrm{HF}$ and for CH FV breeds ( $P=0.50$ and 0.21 , respectively). Conversely, genetic indices differed across farms for the CH BV breed $(P<0.001)$. This was mainly due to low within-farm variability rather than to large across farm dispersion (the coefficient of variation of farmaveraged indices was only $4 \%$ ). These slight differences between farms explain a part of the farm effect, which was included in the statistical models (see the Statistical Analyses section).

\section{Animals}

NZ HF. The $58 \mathrm{NZ} \mathrm{HF} \mathrm{cows} \mathrm{were} \mathrm{of} \mathrm{NZ} \mathrm{genetic}$ origin, a strain of HF selected within seasonal calving pasture-based dairy systems for high milk-component production, fertility, and longevity and for low BW. These animals had at least 2 generations of NZ ancestry, representing $11 \mathrm{NZ} \mathrm{HF}$ sires (74\% from 5 sires), and had an average pedigree index breeding worth of $\mathrm{NZ} \$ 89 \pm 13.5$. They were, therefore, representative of the 2005-born HF in New Zealand (NZ $\$ 87 \pm 42$; October 2009, R. Wood, NZ Animal Evaluation Limited, Hamilton, New Zealand, personal communication).

$\boldsymbol{C H} \boldsymbol{H F}$. The $24 \mathrm{CH}$ HF cows were from a HF strain of NA origin, but selected for a breeding index that included both milk production and functional traits. These animals represented $18 \mathrm{CH}$ HF sires. Their average pedigree index for milk production was $103 \pm 6.5$. They were, therefore, representative of the 2005-born HF in Switzerland (104 \pm 9.3 pedigree index for milk 
production; November 2009, E. Barras, Holstein Association of Switzerland, Posieux, Switzerland, personal communication).

$\boldsymbol{C H} \boldsymbol{F} \boldsymbol{V}$. The $27 \mathrm{CH} \mathrm{FV} \mathrm{cows} \mathrm{were} \mathrm{the} \mathrm{result} \mathrm{of} \mathrm{sev-}$ eral generations of crosses between Simmental and Red Holstein breeds, with an average of $68 \pm 12 \%$ Red Holstein genetics. The hybrid vigor effects were considered as negligible. The herd society's breeding objectives include milk production, functional traits, and beef characteristics. These animals represented $21 \mathrm{CH}$ FV sires. Their average pedigree index for milk production was $106 \pm 6.0$. They were, therefore, representative of the $\mathrm{CH} F \mathrm{FV}$ living population $(101 \pm 9.8$ pedigree index for milk production; November 2009, A. Bigler, Swissherdbook, Zollikofen, Switzerland, personal communication).

$\boldsymbol{C H} \boldsymbol{B S}$. The $25 \mathrm{CH}$ BS were BS cows, mainly of NA origin, with only $6 \pm 5 \%$ original BS genetics. They were selected using a balanced breeding index, including milk production and functional traits. These animals represented $17 \mathrm{CH}$ BS sires. Their average pedigree index for milk production was $103 \pm 5.6$. They were, therefore, representative of the 2005-born Brown Swiss in Switzerland (104 \pm 7.9 pedigree index for milk production; November 2009, B. Bapst, Swiss Brown Cattle Breeders' Federation, Zug, Switzerland, personal communication).

\section{Farms and Herd Management}

Farms. The 15 farms were located in different geographical regions and at different altitudes. Nine were located on the Swiss plateau (lowland), 4 in the preAlps (hill country), and 2 in the Jura (hill and mountain country), with an altitude ranging from 430 to $1,050 \mathrm{~m}$ and vegetation growth period ranging from 230 to $170 \mathrm{~d}$ (Federal Office for Agriculture, 2013). Grazing system was rotational for 11 farms and continuous for 4 farms. Management objectives were similar between herds (low-input, pasture-based, spring-calving system).

Feeding. The winter lactating cow ration (from calving to the start of grazing at $35 \pm 28$ DIM) contained a grass-sourced forage: hay, hay and grass silage, or grass silage and maize silage ( $\mathrm{n}=7,6$, and 2 farms, respectively). Concentrates were fed daily at a rate of $3.2 \pm$ $1.6 \mathrm{~kg}$ of $\mathrm{DM} /$ cow to lactating cows during the winter period (mean $260 \pm 130 \mathrm{~kg} / \mathrm{cow}$ per lactation). Winter rations were estimated to contain $6.2 \pm 0.5 \mathrm{MJ}$ of $\mathrm{NE}_{\mathrm{L}} /$ $\mathrm{kg}$ of $\mathrm{DM}$ and $14 \pm 2 \% \mathrm{CP} / \mathrm{kg}$ of DM (1 sample/forage type per farm per year). Cows were managed on pasture from March 25 ( $\pm 13 \mathrm{~d})$ to November $11( \pm 11 \mathrm{~d})$, with 2 - to 3-wk transition periods between indoor feeding and grazing only. At grazing, supplementary feed was offered only during periods of pasture deficit. The offered pasture contained $6.2 \pm 0.3 \mathrm{MJ}$ of $\mathrm{NE}_{\mathrm{L}} / \mathrm{kg}$ of $\mathrm{DM}$ and $21 \pm 4 \% \mathrm{CP} / \mathrm{kg}$ of $\mathrm{DM}$ (estimated from 1 sample of offered pasture/month per farm). The dry period ration consisted of hay or grass silage of lower quality than the lactating cow ration.

Reproductive Events. The average day of the planned start of mating (PSM) was April 16 ( $\pm 15 \mathrm{~d})$. Five, 3, and 1 farm in 2007, 2008, and 2009, respectively, did not follow strict seasonal rules and did not have fixed PSM dates. For the cows on these farms, artificial PSM dates were calculated for each cow by adding a voluntary waiting period to the calving date. The voluntary waiting period was defined for each farm as the shortest observed interval from calving to service $(48 \pm 11 \mathrm{~d})$. A mating period of 12 wk after PSM was set for all farms. Any mating that occurred after 12 wk was not included in the analysis. All calving dates, AI dates, health events, and treatments were recorded. For cows not showing estrus before PSM, the need for treatment was assessed individually by the farm veterinarian. From the 15 farms, 6 introduced a bull into the herd $41 \pm 13$ days after PSM (i.e., after 2 AI cycles), and 9 farms used only AI during the 12 wk not followed by natural mating.

\section{Animal Measurements and Variables Computation}

Milk Yield, BCS, and BW. Milk volume and composition were assessed monthly. Samples were analyzed for fat, protein, and lactose content with an infrared analyzer (Foss, Hillerød, Denmark). Energy-corrected milk (4.0\% fat, $3.2 \%$ protein, $4.8 \%$ lactose) was calculated as $\mathrm{ECM}=(0.38 \times \%$ fat $+0.24 \times \%$ protein $+0.17 \times \%$ lactose) $/ 3.14$ (Arrigo et al., 2008). From these monthly records, cumulative variables over 100 or $270 \mathrm{~d}$ of lactation were calculated as

$$
\sum_{i=0}^{n} \frac{\left(\text { value }_{i}+\text { value }_{i+1}\right)}{2} \times\left(\text { days }_{i+1}-\text { days }_{i}\right),
$$

where value $_{i}$ and days ${ }_{i}$ are the value (e.g., milk yield) and days after calving of the $i$ th sample, respectively; $n$ is the number of samples $<100$ or $270 \mathrm{~d}$ after calving; value $_{0}$ is set to value ${ }_{1}$, days ${ }_{0}$ is set to 0 , and days s $_{n+1}$ is set to 100 or 270 days. In addition, Wood lactation curves were fitted over lactation per breed $\left(\mathrm{ECM}_{t}=\mathrm{a} \times t^{b} \times\right.$ $e^{-c \times t}$, where $t$ is the day after calving; Wood, 1967) to analyze the shape of the lactation profile. Body condition score was assessed monthly on a 1- to 5-scale in increments of 0.25 (Edmonson et al., 1989) by the same trained operator across all farms. Calving BCS was considered as the maximum of the 2 one-month-spaced 
scores that framed calving. Body condition score from 30 to $270 \mathrm{~d}$ postpartum was calculated at 30 -d intervals from individually fitted cubic spline smoothing curves (smooth.spline function: smoothing parameter $=0.25$; BCS weights $=5,2$, and 1 at calving, before calving, and after $60 \mathrm{~d}$ postpartum, respectively; R Development Core Team, 2009). Cows were weighed on d $38 \pm$ $22,124 \pm 27$, and $281 \pm 33$ postpartum, using a mobile weigh platform (Tru-Test, Auckland, New Zealand). Lactation BW was averaged over these 3 values and used to calculate milk production efficiency (milk or $\mathrm{ECM}$ yield per $\mathrm{BW}^{0.75}$ ).

Reproductive Parameters and Health. The date of conception was estimated from mating dates and subsequent calving date. When several inseminations were performed within the interval (expected mating date -10 ; expected mating date +14 ), the last insemination date was chosen. In case of late abortion or culling as pregnant, the last mating date was taken as conception date $(\mathrm{n}=6)$. For natural mating without a recorded date, the date of conception was estimated by subtracting the gestation length for the sire's breed to the subsequent calving date. The farmer recorded health events and associated treatments. Nondelivery of fetal membranes, metritis, and severe vaginal discharge were pooled under the term of periparturient disease.

\section{Statistical Analyses}

The analyses were performed using $\mathrm{R}$ statistical software (R Development Core Team, 2009) and the lme4 (Bates and Maechler, 2010), nlme (Pinheiro et al., 2010), and multcomp (Hothorn et al., 2008) packages.

Breed Comparison. Continuous and binomial variables were respectively analyzed by linear mixed models (lmer) and mixed logistic regressions (glmer) that included breed as fixed effect, and cow within breed, year, and farm within year as random effects. The model was

$$
\begin{aligned}
R_{i j k l}=\mu & +B_{i}+\operatorname{year}_{j}+\operatorname{farm}_{k}\left(\text { year }_{j}\right) \\
& +\operatorname{cow}_{l}\left(\mathrm{~B}_{i}\right)+e_{i j k l},
\end{aligned}
$$

where $R_{i j k l}$ is the response for the animal $l$ of breed $i$ in year $j$ and farm $k ; \mu$ is the common intercept; $B_{i}$ is the fixed effect for the breed $(i=1,2,3,4)$; year $_{j}$ is the random effect for year $(j=1,2,3)$; $\operatorname{farm}_{k}\left(\right.$ year $\left._{j}\right)$ is the random effect for farm $(k=1, \ldots, 15)$ nested within year; $\operatorname{cow}_{l}\left(\mathrm{~B}_{i}\right)$ is the random effect for cow $(l=1, \ldots$, 134) nested within breed; and $e_{i j k l}$ is the residual error. Results are expressed as predicted means or probabilities for each breed. Multiple comparison biases were accounted for (multcomp, single-step method). The breeds' Wood lactation profiles were fitted by a linear mixed model (lme) predicting the $\ln \left(\mathrm{ECM}_{t}\right)$ and including breed, day $t$ after calving, $\ln (t)$, and the interactions breed $\times t$ and breed $\times \ln (t)$ as fixed effects and year, farm, cow and the interaction cow $\times t$ as nested random effects. Residuals were modeled using an exponential correlation structure and a variance power of $t$. The model was

$$
\begin{gathered}
\ln (\mathrm{ECM})_{i j k l t}=\mu+B_{i}+t+\ln (t)+\left(B_{i} \times t\right) \\
+\left[B_{i} \times \ln (t)\right]+\operatorname{year}_{j}+\operatorname{farm}_{k}\left(\text { year }_{j}\right) \\
+\operatorname{cow}_{l}\left[\operatorname{farm}_{k}\left(\text { year }_{j}\right)\right]+\operatorname{cow}_{l}\left[\operatorname{farm}_{k}\left(\text { year }_{j}\right)\right] \times t+e_{i j k l t},
\end{gathered}
$$

where $\ln (\mathrm{ECM})_{i j k l t}$ is the natural logarithm of ECM at time $t$ for the animal $l$ of breed $i$ in year $j$ and farm $k$; $\mu$ is the common intercept; $B_{i}$ is the fixed effect for the breed $(i=1,2,3,4) ; t$ is the fixed effect of the DIM covariate; $\ln (t)$ is the natural logarithm of $t ; B_{i} \times t$ is the slope interaction between breed and $t ; B_{i} \times \ln (t)$ is the slope interaction between breed and $\ln (t)$; year ${ }_{j}$ is the random effect for year $(j=1,2,3)$; $\operatorname{farm}_{k}\left(\right.$ year $\left._{j}\right)$ is the random effect for farm $(k=1, \ldots, 15)$ nested within year; $\operatorname{cow}_{l}\left[\operatorname{farm}_{k}\left(\right.\right.$ year $\left.\left._{j}\right)\right]$ is the random effect for cow $(l=1, \ldots, 134)$ nested within farm and within year; $\operatorname{cow}_{l}\left[\operatorname{farm}_{k}\left(\right.\right.$ year $\left.\left._{j}\right)\right] \times t$ is the random slope interaction with $t$; and $e_{i j k l t}$ is the residual error modeled using an exponential correlation structure and a variance power of $t$.

Thirty-day spaced BCS from calving to $270 \mathrm{~d}$ after calving was adjusted in a linear mixed model accounting for breed, time, and their interaction as fixed effects, and year, farm within year, and cow within farm within year as random effects. Residuals were modeled using an autoregressive correlation structure of order 1 . The model was

$$
\begin{aligned}
& \mathrm{BCS}_{i j k l t}=\mu+B_{i}+T_{t}+\left(B_{i} \times T_{t}\right)+\text { year }_{j} \\
& +\operatorname{farm}_{k}\left(\text { year }_{j}\right)+\operatorname{cow}_{l}\left[\operatorname{farm}_{k}\left(\operatorname{year}_{j}\right)\right]+e_{i j k l t},
\end{aligned}
$$

where BCS $_{i j k l t}$ is the BCS at time $t$ for the animal $l$ of breed $i$ in year $j$ and farm $k ; \mu$ is the common intercept; $B_{i}$ is the fixed effect for breed $(i=1,2,3,4) ; T$ is the fixed effect for BCS time $(t=1, \ldots, 10) ; B_{i} \times T_{t}$ is the interaction between breed and BCS time; year ${ }_{j}$ is the random effect for year $(j=1,2,3)$; farm $_{k}\left(\right.$ year $\left._{j}\right)$ is the random effect for farm $(k=1, \ldots, 15)$ nested within year; $\operatorname{cow}_{l}\left[\operatorname{farm}_{k}\left(\right.\right.$ year $\left.\left._{j}\right)\right]$ is the random effect for cow $(l$ $=1, \ldots, 134)$ nested within farm and within year; and $e_{i j k l t}$ is the residual error modeled using an autoregressive correlation structure of order 1 .

Relationships Between Variables. The relationships between reproductive variables and both produc- 
tion and BCS variables were further investigated by mixed logistic regressions (glmer). The 3 reproductive outcome variables investigated were the 21 -d submission rate, the first service conception rate, and the 6 -wk pregnancy rate. The 7 explanatory covariates were total ECM over the first $100 \mathrm{~d}$ of lactation (both the raw value and the value divided by metabolic BW), BCS at calving, BCS at 100 days, BCS at nadir, and BCS change from calving to $100 \mathrm{~d}$ and to nadir. Models accounted for the investigated covariate, breed and their interaction as fixed effects, and cow, year and farm within year as random effects. The initial model was

$$
\begin{aligned}
& \operatorname{Logit}\left(R O_{i j k l}\right)=\mu+B_{i}+\mathrm{COV}+B_{i} \times \mathrm{COV} \\
& +\operatorname{year}_{j}+\operatorname{farm}_{k}\left(\operatorname{year}_{j}\right)+\operatorname{cow}_{l}\left(B_{i}\right)+e_{i j k l}
\end{aligned}
$$

where $R O_{i j k l}$ is the binomial reproductive outcome $(0 / 1)$ for the animal $l$ of breed $i$ in year $j$ and farm $k$; $\mu$ is the common intercept; $B_{i}$ is the fixed effect for the breed $(i=1,2,3,4)$; COV is the investigated covariate; $B_{i}$ $\times \mathrm{COV}$ is the slope interaction between breed and the covariate; year $_{j}$ is the random effect for year $(j=1$, $2,3) ;$ farm $_{k}\left(\right.$ year $\left._{j}\right)$ is the random effect for farm $(k=$ $1, \ldots, 15)$ nested within year; $\operatorname{cow}_{l}\left(B_{i}\right)$ is the random effect for cow $(l=1, \ldots, 134)$ nested within breed; and $e_{i j k l}$ is the residual error. Effects of the covariate were assessed by likelihood ratio tests, sequentially removing the interaction term, covariate or breed, and all fixed effects from the model. Interactions at $P<0.20$ were explored further, eventually by removing an atypical group from the analyzed population. In addition, relationships between ECM and BCS variables were analyzed similarly using linear mixed models (lmer).

\section{RESULTS}

\section{Milk Production and BCS}

All production parameters differed among breeds (Table 1). Milk and ECM yield over $270 \mathrm{~d}$ of lactation differed by 1,000 kg between the 2 extreme groups, with $\mathrm{CH} \mathrm{HF}$ having the highest yield and $\mathrm{CH}$ BS the lowest. The CH BS cows also produced the lowest fat and protein yields, whereas no difference was recorded between NZ HF, CH HF, and CH FV. The NZ HF cows had the highest average fat and protein contents and greatest lactation persistency (expressed as the ratio of ECM yield during d 101 to 200 to the ECM yield during d 1 to 100; Figure 1). Body weight differed by $90 \mathrm{~kg}$ between extremes, with NZ HF and CH BS being the lightest groups and $\mathrm{CH} \mathrm{HF}$ and $\mathrm{CH} \mathrm{FV}$ the heaviest (Table 1). Accounting for BW and ECM differences, the ECM efficiency criteria identified the HF groups
(CH HF and NZ HF) as most efficient (Table 1). Body condition score was also affected by breed $(P<0.001)$, but BCS change was not (Table 1; Figure 1).

\section{Reproduction and Health}

For the same interval from calving to PSM, CH FV cows established pregnancy earlier than other breeds (Figure 2). This was a consequence of a high 21-d submission rate $(86 \%)$ and a high conception rate within 2 inseminations (89\%; Table 2). Conversely, although not always significant, the poorest reproductive performances were recorded for $\mathrm{CH} \mathrm{HF}$ cows, with NZ HF and CH BS being intermediate. Despite a low 21-d submission rate $(53 \%)$, NZ HF reached the same 12-wk pregnancy rate as $\mathrm{CH} \mathrm{FV}$ and $\mathrm{CH}$ BS cows $(>90 \%$; Table 2). The NZ HF cows had a higher prevalence of health disorders during their lactations than $\mathrm{CH}$ BS cows (41 vs. $14 \%$; $P<0.01$; Table 3). Although this could not be statistically attributed to any specific health disorder, a higher prevalence of mastitis was suspected (19 vs. $3 \%$ for NZ HF vs. CH BS; $P=0.11$ ), and supported by SCC data for the first $100 \mathrm{~d}$ of lactation (Table 3).

\section{Relationships Between Reproductive Performance and Milk Production or BCS}

Only BCS at nadir, BCS at $100 \mathrm{~d}$ postpartum, and, to a lesser extent, BCS at calving were associated with variance in reproductive performance. The breed $\times$ covariate interaction term was removed from all models (all $P>0.24$ ). Body condition score at calving was positively associated with first service conception rate $(P=0.062)$ and 6 -wk pregnancy rate $(P=0.027)$, but only if breed was not included in the model (if included $P=0.16$ and 0.12 , respectively); it did not affect 21 -d submission rate with either model $(P>0.16)$. Both BCS at nadir and at $100 \mathrm{~d}$ were positively associated with the 6 -wk pregnancy rate $(P=0.001$ and $P<$ 0.001 , respectively), even when breed was included in the model $(P<0.01$; Figure 3$)$. Body condition score at $100 \mathrm{~d}$ was also positively associated with first service conception rate, either with $(P<0.05)$ or without $(P$ $<0.05$ ) accounting for the breed effect (Figure 3). In comparison, BCS at nadir tended to be associated with variance in first service conception rate $(P=0.07)$, but only if breed was not included in the model (if included $P=0.26$ ). The association between BCS at nadir, and at $100 \mathrm{~d}$, on 21-d submission rate tended to differ among the breeds $(P=0.15$ and 0.16 for the interaction term, respectively). An opposite nonsignificant relationship $(P>0.63)$ was observed in the $\mathrm{CH} \mathrm{HF}$ group. After removing the $\mathrm{CH} \mathrm{HF}$ breed from 
Table 1. Milk production, BW, and BCS of New Zealand Holstein-Friesian (NZ HF), Swiss Holstein-Friesian (CH HF), Swiss Fleckvieh (CH FV), and Swiss Brown Swiss (CH BS) cows managed in a seasonal-calving, pasture-based dairy system

\begin{tabular}{|c|c|c|c|c|c|c|c|}
\hline Item & $\mathrm{n}$ & $\mathrm{NZ} \mathrm{HF}$ & $\mathrm{CH} \mathrm{HF}$ & $\mathrm{CH}$ FV & $\mathrm{CH}$ BS & $P$-value $_{\text {breed }}$ & $\mathrm{SED}_{\max }^{1}$ \\
\hline Milk yield $(\mathrm{kg})$ & 259 & $5,321^{\mathrm{b}}$ & $5,921^{\mathrm{c}}$ & $5,291^{\mathrm{ab}}$ & $4,927^{\mathrm{a}}$ & $<0.001$ & 190 \\
\hline Protein yield (kg) & 259 & $184^{\mathrm{b}}$ & $190^{\mathrm{b}}$ & $175^{\mathrm{b}}$ & $160^{\mathrm{a}}$ & $<0.001$ & 6.01 \\
\hline Fat content $(\%)$ & 259 & $4.25^{\mathrm{c}}$ & $4.01^{\mathrm{ab}}$ & $4.15^{\mathrm{bc}}$ & $3.86^{\mathrm{a}}$ & $<0.001$ & 0.107 \\
\hline Protein content (\%) & 259 & $3.46^{\mathrm{b}}$ & $3.20^{\mathrm{a}}$ & $3.31^{\mathrm{a}}$ & $3.27^{\mathrm{a}}$ & $<0.001$ & 0.048 \\
\hline ECM efficiency ${ }^{4}\left(\mathrm{~kg} \cdot \mathrm{kg}^{-0.75}\right)$ & 221 & $52.1^{\mathrm{b}}$ & $50.2^{\mathrm{b}}$ & $44.5^{\mathrm{a}}$ & $43.8^{\mathrm{a}}$ & $<0.001$ & 1.73 \\
\hline \multicolumn{8}{|l|}{ Milk production over first $100 \mathrm{~d}$} \\
\hline ECM yield ${ }^{1}(\mathrm{~kg})$ & 259 & $2,508^{\mathrm{b}}$ & $2,740^{\mathrm{c}}$ & $2,502^{\mathrm{ab}}$ & $2,322^{\mathrm{a}}$ & $<0.001$ & 87.1 \\
\hline ECM efficiency ${ }^{2}\left(\mathrm{~kg} \cdot \mathrm{kg}^{-0.75}\right)$ & 221 & $23.2^{\mathrm{b}}$ & $22.8^{\mathrm{ab}}$ & $20.9^{\mathrm{a}}$ & $20.9^{\mathrm{a}}$ & $<0.001$ & 1.72 \\
\hline Average body weight & 221 & $514^{\mathrm{a}}$ & $592^{\mathrm{b}}$ & $605^{\mathrm{b}}$ & $523^{\mathrm{a}}$ & $<0.001$ & 14.4 \\
\hline \multicolumn{8}{|l|}{ Body condition (1 to 5 ) } \\
\hline BCS at calving & 251 & $3.25^{\mathrm{b}}$ & $3.05^{\mathrm{a}}$ & $3.52^{\mathrm{c}}$ & $3.38^{\mathrm{bc}}$ & $<0.001$ & 0.099 \\
\hline Maximum BCS loss & 242 & -0.55 & -0.65 & -0.64 & -0.61 & 0.230 & 0.090 \\
\hline
\end{tabular}

${ }^{\mathrm{a}-\mathrm{c}}$ Values within a row with different superscript letters differ $(P<0.05)$.

${ }^{1}$ Maximum of SE of the differences.

${ }^{2}$ Energy-corrected milk: $4.0 \%$ fat, $3.2 \%$ protein, and $4.8 \%$ lactose.

${ }^{3}$ Ratio of ECM yield during d 101 to 200 to the ECM yield during d 1 to 100 .

${ }^{4}$ Energy-corrected milk per average lactation metabolic weight (i.e., per average lactation $\mathrm{BW}^{0.75}$ ). Thirty-eight lactations with missing cow BW were excluded from the analysis.

the analyzed population, the breed $\times$ covariate interaction term was removed from the models $(P>0.28)$. In the NZ HF-CH FV-CH BS subpopulation, an increase in BCS at nadir or at $100 \mathrm{~d}$ after calving was associated with an increased 21-d submission rate, with $(P<0.01)$ or without $(P<0.001)$ accounting for breed (Figure 3$)$. Body condition loss from calving to nadir, or to $100 \mathrm{~d}$ postpartum, ECM yield, and ECM efficiency over the first $100 \mathrm{~d}$ of lactation were not associated with variances in reproductive variables $(P>0.20)$, despite partial correlations with BCS at calving and BCS at nadir (see below).

\section{Relationships Between Milk Production and BCS}

Accounting for the breed, 1 unit of BCS higher at calving was associated with a $261-\mathrm{kg}$ increase in ECM yield $(P<0.001), 0.78$ units of BCS higher was associated with loss from calving to nadir $(P<0.001)$ and, consequently, a 0.22 units of BCS higher at nadir $(P<0.001)$. When considering only the first $100 \mathrm{~d}$ of lactation, the strength of the relationship between BCS change and ECM yield appeared breed specific (interaction $=P<0.05$ ). An increase in ECM yield of $400 \mathrm{~kg}(\sim 1 \mathrm{SD}$ on the whole population) was associated with a larger BCS loss of $0.24,0.16,0.12$, and 0.00 unit (from calving to $100 \mathrm{~d}$ ) in the $\mathrm{CH} \mathrm{HF}$, CH BS, NZ HF, and $\mathrm{CH}$ FV groups, respectively. The same was true for ECM efficiency (interaction $=P<0.05$; results not presented).

\section{DISCUSSION}

This study offered the first opportunity to test the suitability of Swiss breeds in a pasture-based, seasonalcalving system, and to compare them to a reference population of NZ HF. New Zealand HF cows were efficient producers with reasonable fertility. Only CH FV had a better reproductive performance, but with a lower milk production efficiency. The study underlined various breed differences in milk yield, BCS dynamics, reproductive performance, and relationships among those traits.

\section{Milk Production and BCS}

Differences in milk production recorded between $\mathrm{CH}$ $\mathrm{HF}$ and NZ HF are in the same range as previously reported in studies comparing NA HF with NZ HF strains in a similar system of production (Horan et al., 2005a, b; Macdonald et al., 2008). Swiss HF were heavier, produced greater milk volumes with lower fat 

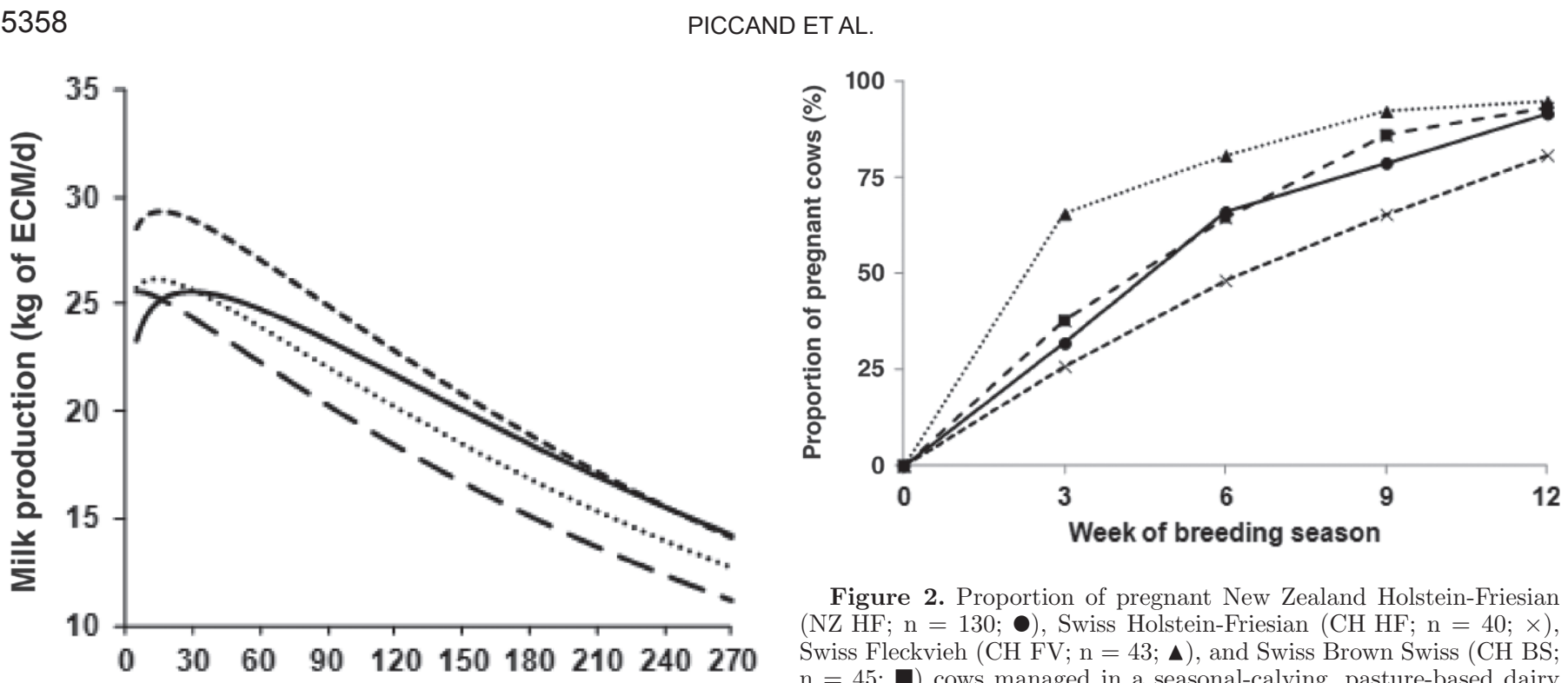

Figure 2. Proportion of pregnant New Zealand Holstein-Friesian (NZ HF; $\mathrm{n}=130 ; \bullet)$, Swiss Holstein-Friesian (CH HF; $\mathrm{n}=40 ; \times)$, Swiss Fleckvieh $(\mathrm{CH} F V ; n=43 ; \mathbf{\Delta})$, and Swiss Brown Swiss (CH BS; $\mathrm{n}=45$; $\mathbf{\square})$ cows managed in a seasonal-calving, pasture-based dairy system.

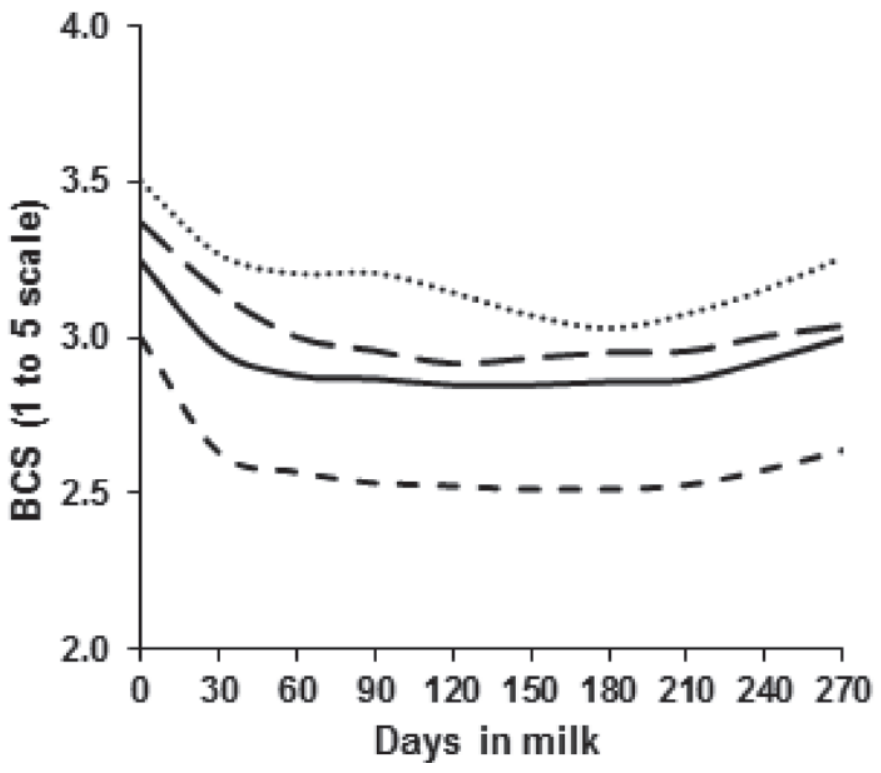

Figure 1. Fitted Wood lactation curves and curves of adjusted BCS over $270 \mathrm{~d}$ of lactation for New Zealand Holstein-Friesian (NZ HF; $\mathrm{n}=$ 131; solid line), Swiss Holstein-Friesian ( $\mathrm{CH}$ HF; $\mathrm{n}=40$; short dashed line), Swiss Fleckvieh (CH FV; $\mathrm{n}=43$; dotted line), and Swiss Brown Swiss (CH BS; $\mathrm{n}=45$; long dashed line) cows managed in a seasonalcalving, pasture-based dairy system.

and protein contents, and had a higher peak of lactation with a lower persistency than NZ HF. As a result, expressed in terms of $\mathrm{kg}$ of $\mathrm{ECM} / \mathrm{kg}$ of $\mathrm{BW}^{0.75}$, both HF strains achieved the same efficiency of production, as reported by Horan et al. (2004a, b) and Kolver et al. (2005) in a similar system of production in terms of quantity of concentrate offered. For this reason, Delaby et al. (2010) has previously argued that high genetic merit dairy cows, even the highest producers within the $\mathrm{HF}$, are also adaptable to low-input grazing dairy sys-

tems if no time-related reproductive constraint exists. However, in a more restrictive system (pasture only), NZ HF achieved a higher milk production efficiency than NA HF (Kolver et al., 2002, 2005; Macdonald et al., 2008). Feeding may not have been restricted enough within the current study to conclude that NZ HF had a higher milk production efficiency. On the contrary, in a pasture system with high concentrate supplementation (average $4-6 \mathrm{~kg} / \mathrm{cow}$ per day), NA HF achieved a higher efficiency (Horan et al., 2004, 2005b; Kolver et al., 2005). This is due to a 2 -fold greater milk response to concentrate supplementation for NA HF than for NZ HF, owing to a lower substitution rate (kilograms of forage less per kilograms of concentrate more) and to a different partitioning of the supplemental energy into milk production rather than into body reserves (Horan et al., 2005b; Roche et al., 2006). The latter is, to some extent, explained by higher insulin resistance (Chagas et al., 2009) and greater uncoupling of the somatotropic axis (Lucy et al., 2009) in NA genetics. In the current study, it could be inferred that the production efficiency and the greater lactation peak of the $\mathrm{CH} \mathrm{HF}$ was due to a greater milk response to concentrate supplementation (i.e., to a greater DMI) before the start of grazing $(3.2 \mathrm{~kg} /$ cow per day), and partly to a higher fat mobilization at the beginning of lactation. With a similar pattern of concentrate supplementation, Horan et al. (2005a) also reported similar lactation curve differences between NA HF and NZ HF. The pattern of concentrate supply may thus influence the peak level achieved, in agreement with the relatively flat curves reported for HF cows fed no concentrate at all between calving and the start of grazing (Cutullic et al., 2011). 
Table 2. Reproduction parameters of New Zealand Holstein-Friesian (NZ HF), Swiss Holstein-Friesian (CH HF), Swiss Fleckvieh (CH FV), and Swiss Brown Swiss (CH BS) cows managed in a seasonal-calving, pasture-based dairy system

\begin{tabular}{|c|c|c|c|c|c|c|c|}
\hline Item & $\mathrm{n}$ & NZ HF & $\mathrm{CH} \mathrm{HF}$ & $\mathrm{CH} \mathrm{FV}$ & CH BS & $P$-value ${ }_{\text {breed }}$ & $\mathrm{SED}_{\max }{ }^{1}$ \\
\hline Calving to $\mathrm{PSM}^{2}(\mathrm{~d})$ & 259 & 55.6 & 56.5 & 57.2 & 51.9 & 0.692 & 5.10 \\
\hline PSM to conception ${ }^{3}(\mathrm{~d})$ & 220 & $27.3^{\mathrm{b}}$ & $29.3^{\mathrm{ab}}$ & $14.8^{\mathrm{a}}$ & $21.9^{\mathrm{ab}}$ & $<0.05$ & $0.622^{3}$ \\
\hline PSM to first service ${ }^{3}$ (d) & 256 & $19.9^{\mathrm{b}}$ & $18.8^{\mathrm{ab}}$ & $11.0^{\mathrm{a}}$ & $13.3^{\mathrm{ab}}$ & $<0.05$ & $0.546^{3}$ \\
\hline $21-\mathrm{d}$ submission rate $(\%)$ & 259 & $52.9^{\mathrm{a}}$ & $57.7^{\mathrm{ab}}$ & $86.0^{\mathrm{b}}$ & $70.5^{\mathrm{ab}}$ & $<0.01$ & - \\
\hline Pregnant within 3 wk of mating (\%) & 258 & $31.9^{\mathrm{a}}$ & $25.8^{\mathrm{a}}$ & $65.4^{\mathrm{b}}$ & $37.6^{\mathrm{ab}}$ & $<0.05$ & - \\
\hline Pregnant within 6 wk of mating (\%) & 258 & 66.0 & 48.1 & 80.6 & 64.4 & 0.144 & - \\
\hline Pregnant within 9 wk of mating (\%) & 258 & $78.6^{\mathrm{ab}}$ & $65.3^{\mathrm{a}}$ & $92.0^{\mathrm{b}}$ & $85.8^{\mathrm{ab}}$ & $<0.05$ & - \\
\hline Pregnant within 12 wk of mating (\%) & 258 & 91.5 & 80.7 & 94.5 & 93.0 & 0.326 & - \\
\hline
\end{tabular}

${ }^{\mathrm{a}-\mathrm{c}}$ Values within a row with different superscript letters differ $(P<0.05)$.

${ }^{1}$ Maximum of SE of the differences for continuous variables only (binomial variables were analyzed on the logit scale).

${ }^{2}$ Planned start of mating.

${ }^{3}$ The variable was transformed by squared root before analysis; $\mathrm{SED}_{\max }$ is given on the squared root scale.

Although $\mathrm{CH} \mathrm{HF}$ cows were thinner throughout, no difference in BCS change over lactation $(P>0.2)$ was observed; the difference of 0.10 units of BCS change between $\mathrm{CH} \mathrm{HF}$ and $\mathrm{NZ} \mathrm{HF}$ was reached within the first $30 \mathrm{~d}$ of lactation and did not widen further. The already lower BCS at calving for CH HF ( -0.20 units of BCS in comparison to NZ HF) may have narrowed the difference in BCS loss, as lower BCS at calving partly prevents excessive BCS loss after calving (Roche et al., 2009). The difference of 0.10 units of BCS change would explain no more than $80 \mathrm{~kg}$ of ECM difference over lactation (National Research Council, 2001). Even the differences in BCS change with the other 2, less efficient, breeds ( $\mathrm{CH} \mathrm{FV}$ and $\mathrm{CH} \mathrm{BS}$ ) did not reach significance $(P>0.1)$. This is not consistent with the studies of Horan et al. (2005b), Roche et al. (2006), McCarthy et al. (2007a) or Macdonald et al. (2008), where NA HF lost more BCS at the beginning of lactation than NZ HF. Similarly, breeds such as Montbeliarde or Normande (breeds comparable with the $\mathrm{CH}$ FV in terms of the balance of milk and meat production) lose less BCS than NA HF in such systems (Dillon et al., 2003; Delaby et al., 2009; Cutullic et al., 2011).

Interestingly, the relationship between milk production and BCS change within the first $100 \mathrm{~d}$ of lactation was breed-specific; the positive relationship did not exist in the dual-purpose $\mathrm{CH}$ FV. The $\mathrm{CH}$ HF cows produced $800 \mathrm{~kg}$ more ECM over $100 \mathrm{~d}$ of lactation and milk production was associated with nearly 0.5 units larger of BCS change; NZ HF and CH BS being intermediate. It is possible that the rapid improvement in milk production potential for $\mathrm{CH}$ HF cows (as in other dairy type breeds) over the last few decades has been driven through increased body fat mobilization rather than enhanced metabolic pathways and high voluntary DMI. The seasonal BCS profile of $\mathrm{CH} \mathrm{FV}$, with a second BCS decline during the summer months, was not recorded in other breeds but is consistent with Roche et al. (2007). The NZ HF, CH HF, and CH BS cows may already have reached their nadir BCS and thus failed to remobilize fat reserves in response to the reduced feed quality (grass energy content) and quantity in summer.

Table 3. Health parameters of New Zealand Holstein-Friesian (NZ HF), Swiss Holstein-Friesian (CH HF), Swiss Fleckvieh (CH FV), and Swiss Brown Swiss (CH BS) cows managed in a seasonal-calving, pasture-based dairy system

\begin{tabular}{|c|c|c|c|c|c|c|c|}
\hline Item & $\mathrm{n}$ & NZ HF & $\mathrm{CH} \mathrm{HF}$ & $\mathrm{CH} \mathrm{FV}$ & $\mathrm{CH}$ BS & $P$-value breed $_{1}$ & $\mathrm{SED}_{\max }^{1}$ \\
\hline Health problem $^{2}(\%)$ & 259 & $41^{\mathrm{b}}$ & $23^{\mathrm{ab}}$ & $39^{\mathrm{ab}}$ & $14^{\mathrm{a}}$ & $<0.01$ & - \\
\hline Periparturient disease $^{2}(\%)$ & 259 & 9 & 9 & 11 & 8 & 0.967 & - \\
\hline Mastitis $^{2}(\%)$ & 259 & 19 & 7 & 6 & 3 & $<0.05$ & - \\
\hline SCC over $100 \mathrm{~d}^{3}(1,000$ cells $/ \mathrm{mL})$ & 259 & $48^{\mathrm{b}}$ & $42^{\mathrm{ab}}$ & $31^{\text {ab }}$ & $29^{\mathrm{a}}$ & $<0.05$ & $0.225^{3}$ \\
\hline SCC over $270 \mathrm{~d}^{3}(1,000$ cells $/ \mathrm{mL})$ & 259 & 56 & 54 & 41 & 41 & 0.071 & $0.203^{3}$ \\
\hline
\end{tabular}

\footnotetext{
${ }^{\mathrm{a}, \mathrm{b}}$ Values within a row with different superscript letters differ $(P<0.05)$.

${ }^{1}$ Maximum of SE of the differences for continuous variables only (binomial variables were analyzed on the logit scale).

${ }^{2}$ Percentages of lactations with at least 1 health disorder.

${ }^{3}$ Somatic cell count; ln-transformed before analysis; $\mathrm{SED}_{\max }$ is presented on the $\ln$ scale.
} 
This inference would require validation. The other classical relationships between BCS at calving, BCS loss, BCS at nadir and milk production were evident for all of the 4 breeds; a higher BCS at calving (not excessive) was associated with increased BCS loss and milk yield, but also with a higher BCS at nadir (Roche et al., 2009).

\section{Reproductive Performance and Health}

The reproductive performance of $\mathrm{CH} \mathrm{HF}$ was the lowest but within the expected range of results for this breed in this type of dairy production system (Horan et al., 2004; Macdonald et al., 2008). Only $58 \%$ of CH HF were submitted to AI during the first $21 \mathrm{~d}$, and may have been a consequence of a poor heat expression given a previous report on progesterone profiles during second lactation (Piccand et al., 2011). This low submission rate, combined with a low conception rate to first and second service (59\%), resulted in fewer than $50 \%$ of cows being pregnant within 6 wk of breeding. Although the proportion of pregnant cows steadily increased, and reached $81 \%$ by the end of the breeding period, the low proportion of early pregnant cows results in a delayed calving that is likely to worsen with time; late pregnant cows have less time to cycle before PSM in the following year and have shorter lactations. In addition, heifers from such cows may be (up to 2-3 mo) younger at first service.

The low 21-d submission rate of the NZ HF was probably due to a late resumption of luteal activity (monitored in second lactation; Piccand et al., 2011), consistent with previous reports involving this genotype (Macmillan, 2002; McNaughton et al., 2003; Macdonald et al., 2008). Hormonal therapy to induce ovulation at the planned start of mating is commonly used to stimulate cycling activity (McNaughton et al., 2003; Macdonald et al., 2008) and, thus, improve the 21-d submission rate of NZ HF cows. In the current study, the use of hormonal treatment was low for all 4 breeds $(<5 \%)$. However, owing to a high conception rate to AI, NZ HF cows compensated and achieved a $66 \%$ pregnancy rate by 6 wk of breeding, which is similar to the level achieved by the HF population in NZ (69.8\%; $\mathrm{Xu}$ and Burton, 2003). This result also suggests that breeds with late resumption of ovarian activity can even achieve high fertility at insemination, and that failures in cyclicity and conception rate are not mediated by the same genetic factors (Cutullic et al., 2012).

The main disadvantage of NZ HF in the present study was their rather high prevalence of health problems (41\% of lactations experienced at least 1 health issue), especially in comparison with $\mathrm{CH}$ BS group, which were not as efficient with production or reproduction,
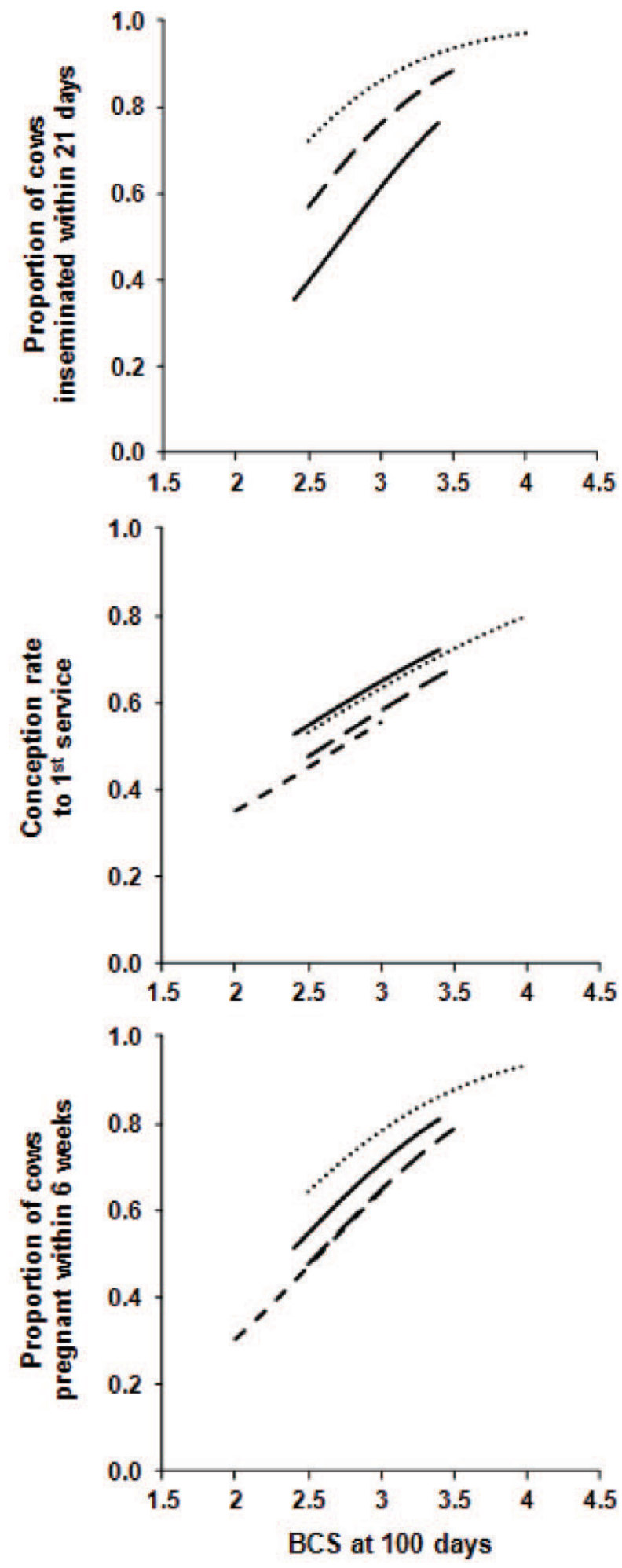

Figure 3. Relationships between BCS at 100 DIM and the 3 reproductive variables - 21-d submission rate $(\mathrm{n}=207)$, first-service conception rate $(\mathrm{n}=252)$, and 6 -wk pregnancy rates $(\mathrm{n}=254)$-in New Zealand Holstein-Friesian (solid line), Swiss Holstein-Friesian (short dashed line), Swiss Fleckvieh (dotted line), and Swiss Brown Swiss (long dashed line) dairy cows bred in a pasture-based, seasonal-calving system. Detailed equations can be found in Table A1 of the Appendix. 
but encountered relatively few health problems (13\%). Numbers of animals were low to study health problems, but a higher sensitivity to IMI appeared in the NZ HF cows used in this study. When considering SCC, the results are more ambiguous, as also reported in other studies where NA HF had higher (Lacy-Hulbert et al., 2002) or lower SCC (McCarthy et al., 2007b; Macdonald et al., 2008) than NZ HF. Statistical trends were only observed over the first $100 \mathrm{~d}$ of lactation between $\mathrm{NZ} \mathrm{HF}$ and $\mathrm{CH}$ BS $(P<0.05)$ or $\mathrm{CH} \mathrm{FV}(P=0.06)$. Swiss breeds have been selected for a longer time on SCC and udder characteristics compared with NZ HF where the SCC trait was introduced in the NZ breeding worth calculations in 2004. Udder health should require further consideration, as it is a major culling reason in dairy herds and consumer pressures to reduce antibiotic use exist.

Reproductive performance of $\mathrm{CH} F \mathrm{~F}$ was the best among the 4 breeds studied. They were the only breed to achieve, or even exceed, the objectives set for seasonalcalving herds $(\geq 90 \%$ submission rate in $21 \mathrm{~d}$ and $\geq 78 \%$ of cows pregnant within 6 wk of breeding; Burke et al., 2007). This result is in agreement with the average from the Swiss national records, irrespective of the production system; CH FV achieved very high conception rates, good estrus expression (as demonstrated by the high 21-d submission rate, which is the result of heat expression and detection rate), and early and regular cyclicity (attested in second lactation by progesterone profiles; Piccand et al., 2011). The superior reproductive performance of Montbeliarde or Normande (breeds comparable with the $\mathrm{CH} \mathrm{FV}$ in terms of the balance of milk and meat production) in seasonal-calving systems has already been reported (Dillon et al., 2003; Delaby et al., 2009; Cutullic et al., 2011). However, those breeds are less efficient milk producers and revenue from meat production must be greater or environmental considerations must be taken into account (Puillet et al., 2012) for these breeds to be recommended.

Interestingly, reproductive performance was closely associated with BCS; CH FV cows were the fattest and had the best results, CH HF cows were the thinnest and had the poorest results, CH BS and NZ HF were intermediate for both BCS and reproductive performance. This is why the effect of variables related to BCS level was increased by removing the breed term from the models. However, even when accounting for the breed effect, BCS at $100 \mathrm{~d}$ postpartum or at nadir was significantly related to the 21-d submission rate (except for the $\mathrm{CH} \mathrm{HF}$ ) and the 6-wk pregnancy rate. Body condition score at $100 \mathrm{~d}$, which is around mating, was also positively associated with first service conception rate. Overall, a higher BCS after calving was associated with improved reproductive performance, irrespective of breed (Figure 3). This is consistent with previous results in such a system (Roche et al., 2007) and may result from improvements in cyclicity, oocyte quality, and conception rate (Cutullic et al., 2012). Reproductive performance is often thought to be influenced both by the BCS level (also at calving) and by the loss of BCS after calving (Roche et al., 2009). Body condition score at $100 \mathrm{~d}$ after calving combines these 2 traits and is, thus, more likely to be highly influential. This should be a serious consideration for fertility selection measures, as BCS is scored once after calving in many dairy countries and the relationships appear common to several breeds. Whereas BCS seems to explain most of the breed differences in first service conception rate and 6-wk pregnancy rate (the breed effect is far from significant when the prediction already accounts for BCS; Figure 3), BCS is clearly not the only factor to explain breed differences on 21-d submission rate. Scoring biases cannot be ruled out, as illustrated by the much lower 21-d submission rate in NZ HF cows compared with $\mathrm{CH}$ FV cows for a same 2.75 BCS at $100 \mathrm{~d}$ after calving ( 51 vs. $80 \%$; Figure 3). The lack of effect of milk yield variables, known for their influence on estrus expression and late embryo survival (Cutullic et al., 2012), is probably due to the relatively lower milk yields achieved in grazing systems where the individual animal is unable to express their milk yield potential, and is in agreement with low phenotypic correlations between milk yield and reproduction reported in Ireland for such systems (Berry et al., 2003). Within the same system, and especially in challenging low-input systems, BCS after calving appears once more to be the critical issue for dairy cattle reproductive improvement (Roche et al., 2009), irrespective of the breed (breed $\times$ BCS interactions were not significant). Pasturefed cows with lower milk yields and BCS can achieve similar reproductive performance than highly supplemented cows with higher milk yields and high BCS, as levels of milk production and BCS are altering specific stages of the reproductive process (Cutullic et al., 2011; Cutullic et al., 2012). For this reason, selection across systems must be done carefully and these effects should be taken into consideration.

\section{CONCLUSIONS}

The results of this analysis indicate large variation between breeds regarding milk production, reproductive performance, and health. Despite their high milk-production efficiency, $\mathrm{CH} \mathrm{HF}$ are unsuited to seasonal calving production systems due to their poor reproductive ability. On the contrary, CH FV achieved compact calving and merit further consideration within pasture-based milk production systems despite their 
lower milk production per lactation. These results also indicate that genetic selection for higher BCS postpartum should help to improve overall reproductive performance irrespective of breed.

\section{ACKNOWLEDGMENTS}

This study was funded by the Swiss Federal Commission for Innovation and Technology, the Swiss College of Agriculture, Swissgenetics, and the Swiss Interest Group for Pasture Based Milk (IG Weidemilch). It was a joint project with the Swiss College of Agriculture, the Research Station Agroscope Liebefeld-Posieux ALP, Vetsuisse Faculty Zurich, and the University of Veterinary Medicine, Vienna (Austria). The authors acknowledge C. R. Burke, DairyNZ, for his advice in analysis of reproductive performance. The authors acknowledge the farmers for their work and engagement, as well as employees of the various institutes who helped in data sampling and recording.

\section{REFERENCES}

Arrigo, Y., C. Chaubert, R. Daccord, D. Gagnaux, H. Gerber, D. Guidon, F. Jans, J. Kessler, E. Lehmann, I. Morel, A. Münger, M. Rouel, U. Wyss, B. Jeangros, and J. Lehmann. 2008. Apports alimentaires recommandés pour les ruminants. Agroscope LiebefeldPosieux, Posieux, Switzerland.

Bates, D., and M. Maechler. 2010. lme4: Linear mixed-effects models using S4 classes. R package version 0.999375-35. Accessed Jan. 10, 2011. http://CRAN.R-project.org/package=lme4.

Berry, D. P., F. Buckley, P. Dillon, R. D. Evans, M. Rath, and R. F. Veerkamp. 2003. Genetic relationships among body condition score, body weight, milk yield, and fertility in dairy cows. J. Dairy Sci. 86:2193-2204.

Böbner, C. 1994. Schätzung wirtschaftlicher Gewichte für sekundäre Leistungsmerkmale bei Schweizerischen Zweinutzungsrindern unter Anwendung der dynamischen Optimierung. PhD Thesis. Swiss Federal Institute of Technology (ETH), Zürich, Switzerland.

Burke, C. R., M. B. Blackwell, and S. Little. 2007. The InCalf Book for New Zealand Dairy Farmers. Hamilton, New Zealand.

Chagas, L. M., M. C. Lucy, P. J. Back, D. Blache, J. M. Lee, P. J. S. Gore, A. J. Sheahan, and J. R. Roche. 2009. Insulin resistance in divergent strains of Holstein-Friesian dairy cows offered fresh pasture and increasing amounts of concentrate in early lactation. J. Dairy Sci. 92:216-222.

Cutullic, E., L. Delaby, Y. Gallard, and C. Disenhaus. 2011. Dairy cows' reproductive response to feeding level differs according to the reproductive stage and the breed. Animal 5:731-740.

Cutullic, E., L. Delaby, Y. Gallard, and C. Disenhaus. 2012. Towards a better understanding of the respective effects of milk yield and body condition dynamics on reproduction in Holstein dairy cows. Animal 6:476-487.

Delaby, L., P. Faverdin, G. Michel, C. Disenhaus, and J. L. Peyraud 2009. Effect of different feeding strategies on lactation performance of Holstein and Normande dairy cows. Animal 3:891-905.

Delaby, L., B. Horan, M. O'Donovan, Y. Gallard, and J. L. Peyraud. 2010. Are high genetic merit dairy cows compatible with low input grazing systems? Pages 928-930 in Grassland Science in Europe 15. Proceedings of the 23rd General Meeting of the European Grassland Federation, Kiel, Germany.

Dillon, P., F. Buckley, P. O'Connor, D. Hegarty, and M. Rath. 2003. A comparison of different dairy cow breeds on a seasonal grass-based system of milk production: 1. Milk production, live weight, body condition score and DM intake. Livest. Prod. Sci. 83:21-33.

Edmonson, A. J., I. J. Lean, L. D. Weaver, T. Farver, and G. Webster. 1989. A body condition scoring chart for Holstein dairy cows. J. Dairy Sci. 72:68-78.

Federal office for Agriculture. 2013. Agricultural zones. Map of the zones. Climate for forage production. Accessed Apr. 21, 2013 http://map.geo.admin.ch/?topic $=$ blw.

Fulkerson, W. J., T. M. Davison, S. C. Garcia, G. Hough, M. E. Goddard, R. Dobos, and M. Blockey. 2008. Holstein-Friesian dairy cows under a predominantly grazing system: Interaction between genotype and environment. J. Dairy Sci. 91:826-839.

Hagger, C. 2005. Estimates of genetic diversity in the brown cattle population of Switzerland obtained from pedigree information. J. Anim. Breed. Genet. 122:405-413.

Harris, B. L., and E. S. Kolver. 2001. Review of Holsteinization on intensive pastoral dairy farming in New Zealand. J. Dairy Sci 84:E56-E61.

Holmes, C. W., I. M. Brookes, D. J. Garrick, D. D. S. Mackenzie, T. J. Parkinson, and G. F. Wilson. 2007. Milk Production from Pasture. Principles and Practices. Massey University, Palmerston North, New Zealand.

Horan, B., P. Dillon, D. P. Berry, P. O'Connor, and M. Rath. 2005a. The effect of strain of Holstein-Friesian, feeding system and parity on lactation curves characteristics of spring-calving dairy cows. Livest. Prod. Sci. 95:231-241.

Horan, B., P. Dillon, P. Faverdin, L. Delaby, F. Buckley, and M. Rath. 2005b. The interaction of strain of Holstein-Friesian cows and pasture-based feed systems on milk yield, body weight, and body condition score. J. Dairy Sci. 88:1231-1243.

Horan, B., J. F. Mee, M. Rath, P. O'Connor, and P. Dillon. 2004 The effect of strain of Holstein-Friesian cow and feeding system on reproductive performance in seasonal-calving milk production systems. Anim. Sci. 79:453-467.

Hothorn, T., F. Bretz, and P. Westfall. 2008. Simultaneous inference in general parametric models. Biom. J. 50:346-363.

Kolver, E. S., J. R. Roche, C. R. Burke, and P. W. Aspin. 2005. Influence of dairy cow genotype on milksolids, body condition and reproduction response to concentrate supplementation. Proc. N.Z. Soc. Anim. Prod. 65:46-52.

Kolver, E. S., J. R. Roche, M. J. de Veth, P. L. Thorne, and A. R. Napper. 2002. Total mixed rations versus pasture diets: Evidence for a genotype $\times$ diet interaction in dairy cow performance. Proc. N.Z. Soc. Anim. Prod. 62:246-251.

Lacy-Hulbert, S. J., E. S. Kolver, J. H. Williamson, and A. R. Napper 2002. Incidence of mastitis among cows of different genogtypes in differing nutritional environments. Proc. N.Z. Soc. Anim. Prod. 62:24-29.

Lucy, M. C., G. A. Verkerk, B. E. Whyte, K. A. Macdonald, L. Burton, R. T. Cursons, J. R. Roche, and C. W. Holmes. 2009. Somatotropic axis components and nutrient partitioning in genetically diverse dairy cows managed under different feed allowances in a pasture system. J. Dairy Sci. 92:526-539.

Macdonald, K. A., G. A. Verkerk, B. S. Thorrold, J. E. Pryce, J. W. Penno, L. R. McNaughton, L. J. Burton, J. A. S. Lancaster, J. H. Williamson, and C. W. Holmes. 2008. A comparison of three strains of Holstein-Friesian grazed on pasture and managed under different feed allowances. J. Dairy Sci. 91:1693-1707.

Macmillan, K. L. 2002. Advances in bovine theriogenology in New Zealand. 1. Pregnancy, parturition and the postpartum period. N Z. Vet. J. 50:67-73.

McCarthy, S., D. P. Berry, P. Dillon, M. Rath, and B. Horan. 2007a. Influence of Holstein-Friesian strain and feed system on body weight and body condition score lactation profiles. J. Dairy Sci. 90:1859-1869.

McCarthy, S., D. P. Berry, P. Dillon, M. Rath, and B. Horan. 2007b. Effect of strain of Holstein-Friesian and feed system on udder health and milking characteristics. Livest. Sci. 107:19-28.

McNaughton, L. R., G. A. Verkerk, T. J. Parkinson, K. A. Macdonald, and C. W. Holmes. 2003. Postpartum anoestrous intervals and reproductive performance of three genotypes of Holstein-Friesian 
dairy cattle managed in a seasonal pasture-based dairy system. Proc. N.Z. Soc. Anim. Prod. 63:77-81.

National Research Council. 2001. Nutrient Requirements of Dairy Cattle. Natl. Acad. Press, Washington, DC.

Peyraud, J. L., A. van den Pol-van Dasselaar, P. Dillon, and L. Delaby. 2010. Producing milk from grazing to reconcile economic and environmental performances. Pages 865-879 in Grassland Science in Europe 15. Proceedings of the 23rd General Meeting of the European Grassland Federation, Aug. 29-Sep. 2, 2010, Kiel, Germany.

Piccand, V., S. Meier, E. Cutullic, S. Weilenmann, P. Thomet, F. Schori, C. R. Burke, D. Weiss, J. R. Roche, and P. Kunz. 2011. Ovarian activity in Fleckvieh, Brown Swiss and two strains of Holstein-Friesian cows in pasture-based, seasonal calving dairy system. J. Dairy Res. 78:464-470.

Pinheiro, J., and D. Bates. S. DebRoy, S. Deepayan, and R Development Core Team. 2010. nlme: Linear and Nonlinear Mixed Effects Models. R package version 3.1-97. Accessed Jan. 10, 2011. http:// CRAN.R-project.org/package $=$ nlme.

Puillet, L., J. Agabriel, J. L. Peyraud, and P. Faverdin. 2012. Achieving national production and reducing emissions in cattle farming: An evaluation of different technical choices with a French herd model. Pages 53-56 in Renc. Rech. Ruminants, 19. INRA, Paris, France.

R Development Core Team. 2009. R: A Language and Environment for Statistical Computing. R Foundation for Statistical Computing. Vienna, Austria.
Roche, J. R., D. P. Berry, and E. S. Kolver. 2006. Holstein-Friesian strain and feed effects on milk production, body weight, and body condition score profiles in grazing dairy cows. J. Dairy Sci. 89:3532-3543.

Roche, J. R., N. C. Friggens, J. K. Kay, M. W. Fisher, K. J. Stafford, and D. P. Berry. 2009. Invited review: Body condition score and its association with dairy cow productivity, health, and welfare. J. Dairy Sci. 92:5769-5801.

Roche, J. R., K. A. Macdonald, C. R. Burke, J. M. Lee, and D. P. Berry. 2007. Associations among body condition score, body weight, and reproductive performance in seasonal-calving dairy cattle. J. Dairy Sci. 90:376-391.

Thomet, P., E. Cutullic, W. Bisig, C. Wuest, M. Elsaesser, S. Steinberger, and A. Steinwidder. 2011. Merits of full grazing systems as a sustainable and efficient milk production strategy. Pages 273-285 in Grassland Farming and Land Management Systems in Mountainous Regions. Proceedings of the 16th Symposium of the European Grassland Federation, Irdning, Austria.

Wood, P. D. P. 1967. Algebraic model of the lactation curve in cattle. Nature 216:164-165.

Xu, Z. Z., and L. J. Burton. 2003. Reproductive performance of dairy cows in New Zealand. Final report of the monitoring fertility project, Hamilton, New Zealand. Livestock Improvement Corp., Hamilton, New Zealand.

\section{APPENDIX}

Table A1. Fixed effects coefficients of the linear predictor of the logistic regressions used to model relationships between BCS at 100 DIM and the 3 reproductive variables - 21-d submission rate $(\mathrm{n}=207)$, first service conception rate $(\mathrm{n}=252)$, and 6 -wk pregnancy rates $(\mathrm{n}=254)$ - in New Zealand Holstein-Friesian (NZ HF), Swiss Holstein-Friesian (CH HF), Swiss Fleckvieh (CH FV), and Swiss Brown Swiss (CH BS) dairy cows bred in pasture-based, seasonal-calving systems ${ }^{1}$

\begin{tabular}{lccc}
\hline & \multicolumn{3}{c}{ Model } \\
\cline { 2 - 4 } Coefficient & 21-d submission & First-service conception & 6-wk pregnancy \\
\hline Intercept & -4.8228 & -1.91168 & -3.2992 \\
BCS100 & 1.7652 & 0.84383 & 1.3994 \\
Breed & & 0 & 0 \\
NZ HF & 0 & -0.39354 & -0.3156 \\
CH HF & $\mathrm{NA}^{2}$ & -0.07235 & 0.3815 \\
CH FV & 1.3584 & -0.28562 & -0.2991 \\
CH BS & 0.6871 & & \\
\hline
\end{tabular}

${ }^{1}$ The link function was the logit function: $\operatorname{logit}\left(p_{x i}\right)=\log \left[p_{x i} /\left(1-p_{x i}\right)\right]=$ intercept $+\mathrm{BCS}_{100}+$ breed $_{i}$, where $p_{x i}$ is the probability of success for the $i$ th breed when BCS100 is equal to $x$, intercept and BCS100 are common coefficients to the 4 breeds, and breed $_{i}$ is the breed-specific coefficient corresponding to the $i$ th breed.

${ }^{2}$ Not available. 